\title{
Supercycle in great earthquake recurrence along the Japan Trench over the last 4000 years
}

Kazuko Usami ${ }^{1,5 *} \mathbb{D}$, Ken Ikehara', Toshiya Kanamatsu² and Cecilia M. McHugh ${ }^{3,4}$

\begin{abstract}
On the landward slope of the Japan Trench, the mid-slope terrace (MST) is located at a depth of 4000-6000 m. Two piston cores from the MST were analyzed to assess the applicability of the MST for turbidite paleoseismology and to find out reliable recurrence record of the great earthquakes along the Japan Trench. The cores have preserved records of $\sim 12$ seismo-turbidites (event deposits) during the last 4000 years. In the upper parts of the two cores, only the following earthquakes (magnitude M 8 and larger) were clearly recorded: the 2011 Tohoku, the 1896 Sanriku, the 1454 Kyotoku, and the 869 Jogan earthquake. In the lower part of the cores, turbidites were deposited alternately in the northern and southern sites during the periods between concurrent depositional events occurring at intervals of 500-900 years. Considering the characteristics of the coring sites for their sensitivity to earthquake shaking, the concurrent depositional events likely correspond to a supercycle that follows giant $(M \sim 9)$ earthquakes along the Japan Trench. Preliminary estimations of peak ground acceleration for the historical earthquakes recorded as the turbidites imply that each rupture length of the 1454 and 869 earthquakes was over $200 \mathrm{~km}$. The earthquakes related to the supercycle have occurred over at least the last 4000 years, and the cycle seems to have become slightly shorter in recent years. Earthquakes off the Sanriku coast forming the alternative deposition of turbidites in the two cores have released a part of accumulated slip, as indicated by the turbidites deposited in only one core. Decreases in the release of accumulated slip have possibly caused the recent shortening of the supercycle.
\end{abstract}

Keywords: Japan Trench, Earthquake, Turbidite, Supercycle

\section{Background}

The 2011 off the Pacific coast of Tohoku earthquake (2011 Tohoku earthquake) occurred on March 11, 2011. It was an interplate earthquake that occurred along the Japan Trench with Mw 9.0 (Suzuki et al. 2011). This earthquake triggered huge destructive tsunamis that hit the Pacific coast of Northeast Japan, thus causing extensive damage. This earthquake forced a revision of the conventional understanding of the recurrence patterns of great earthquakes along the Japan Trench (Satake 2015). These recurrence patterns have conventionally been studied through historical and instrumental records on

\footnotetext{
*Correspondence: k-usami@aist.go.jp; k-usami@aori.u-tokyo.ac.jp ${ }^{5}$ Atmosphere and Ocean Research Institute, The University of Tokyo, 5-1-5, Kashiwanoha, Kashiwa-shi, Chiba 277-8564, Japan Full list of author information is available at the end of the article
}

the last few centuries. Therefore, the use of geological records has become more important source of long timescale evidence about the recurrence of great earthquakes.

Onshore tsunami deposits provide evidence that significant earthquakes and tsunamis have impacted the Pacific coast of Tohoku in the past (Abe et al. 1990; Minoura and Nakaya 1991; Minoura et al. 2001; Sawai et al. 2012, 2015; Ishimura and Miyauchi 2015; Takada et al. 2016; Ishimura 2017). Even before the 2011 Tohoku earthquake, two earthquakes along the Japan Trench (the A.D. 869 Jogan earthquake and the 1454 Kyotoku earthquake) that generated giant tsunamis similar to the one in 2011 are indicated by historical records and tsunami deposits (Satake et al. 2008; Namegaya and Yata 2014; Sawai et al. 2015). The 1896 Sanriku earthquake known as "tsunami earthquake" also caused serious damage to the Tohoku region (Kanamori 1972; Tanioka and Satake 1996; Satake 
et al. 2017) and formed tsunami deposits (e.g., Takada et al. 2016). Although tsunamis that originated at great distances have also produced some onshore deposits on the Sanriku coast (e.g., the 1960 Chilean tsunami deposits; Kon'no et al. 1961), the major cause of large tsunamis in this area is interplate earthquakes along the Japan Trench (Minoura and Nakaya 1991; Minoura et al. 2001; Namegaya and Satake 2014; Sawai et al. 2015). However, submarine landslides could also cause some large tsunamis (Tappin et al. 2001; Kawamura et al. 2014). In general, it is difficult to discern the cause of a tsunami solely on the basis of the characteristics of onshore tsunami deposits. Seismo-turbidites (turbidites deposited by earthquake-triggered turbidity currents) have been also used to estimate the recurrence history of earthquakes in other active tectonic margins (Goldfinger et al. 2012; Gutierrez-Pastor et al. 2013; Pouderoux et al. 2014; Patton et al. 2015). According to analysis of turbidites corresponding to the 2011 Tohoku earthquake, the upper few centimeters of surface sediments (as distinct from largescale slope failure) were the primary contributors to sediment remobilization along the Japan Trench when the 2011 earthquake occurred (Ikehara et al. 2016; McHugh et al. 2016). Repeated depositions of seismo-turbidites due to similar remobilizations of surface sediments are speculated to have occurred along the Japan Trench.

On the landward slope of the Japan Trench, the midslope terrace (MST) is recognized at a depth of 4000$6000 \mathrm{~m}$ (Fig. 1A; Cadet et al. 1987). This terrace was reported by the Deep Sea Drilling Project Leg 57 as an area with turbidites at a high sedimentation rate (Shipboard Scientific Party 1980), and thus, the terrace is expected to be suitable for seismo-turbidite analysis.

The Pacific plate subducts beneath the North America plate (Okhotsk plate) at a rate of $\sim 8.6 \mathrm{~cm} /$ year (DeMets et al. 2010). This subduction is associated with tectonic erosion that results in forearc subsidence (von Huene and Lallemand 1990). The episodic subsidence in the forearc slope forms an isolated basin, where upper-slope sediment is trapped. The trapped sediments have been resulting in stratified onlapping formations (Fig. 1C; Arai et al. 2014). In addition, obvious submarine canyons are not present (Fig. 1A). This means that no direct pathway allows the long-distance transportation of terrigenous and coastal sediments. As a result, the MST is difficult to be affected by meteorological and tsunami events in terms of its sediment supply. These bathymetrical conditions provide "linear sources" of sediments to the MST that faces a deep-sea steep landward slope $\left(>5^{\circ}\right)$. The "linear sources" means that few lateral migrations on sediment transport (Reading and Richards 1994). Thus, the origin of sediment on the MST is basically confined to sediments on adjacent landward slope. This condition is useful for identifying the area of earthquakes that triggered turbidity currents resulting in the turbidites in the MST.

The MST has been formed by continuous fault activity associated with the backstop interface (Fig. 1C). The resulting landward-dipping basement under the MST has been filled by stratified strata derived from slope sediments, which have flattened the terrace (von Huene et al. 1980; von Huene and Culotta 1989; Tsuru et al. 2002). The terrace has a trench-ward edge with undulating features that originate from frontal prism structures. These features trap the gravity flow from the landward slope, and then deposit their transporting sediments (von Huene and Culotta 1989; Tsuru et al. 2002). Consequently, the sedimentological conditions lead to the high sedimentation rate of the MST. This high sedimentation rate is expected to be effective for successive recording of the earthquakes.

In this way, MST is speculated to be suitable for seismo-turbidite analysis; however, the sedimentological information in previous studies is limited. Therefore, we analyzed two piston cores from the MST to assess the applicability of the MST for turbidite paleoseismology, and to find out reliable recurrence record of the great earthquakes along the Japan Trench. The two cores PC08 $\left(39.2741^{\circ} \mathrm{N}, 143.9447^{\circ} \mathrm{E} ; 4983 \mathrm{~m}\right.$ depth) and PC10 $\left(39.1206^{\circ} \mathrm{N}, 143.9026^{\circ} \mathrm{E} ; 5398 \mathrm{~m}\right.$ depth) were recovered from different small basins in the MST, during the NT13-19 cruise with $R / V$ Natsushima (Fig. 1A, B). Both cores show relatively clear sedimentary structures, compared to all 23 cores recovered from a broad area of the MST during the cruise (all the coring sites are shown in: McHugh et al. 2016). The hemipelagites of these cores are intercalated by obvious event deposits (about three layers per $1 \mathrm{~m}$ ). Such structures of the two cores are considered to be suitable for the foregoing objective. Because it is difficult to figure out the depositional interval of the event deposits using too many (amalgamated) or too small number of event deposit layers in the core. The two coring sites are $\sim 20 \mathrm{~km}$ apart. This distance is relatively small considering the scale of the Japan Trench. However, it is expected that the core selection provides relatively simple sedimentological and seismological conditions, ensuring reliability of the records by the correlations between the two cores. In this study, we finally conduct a comparison of the records from offshore seismo-turbidites with onshore tsunami deposits, and offer new insights into the recurrence interval and characteristics of great earthquakes that have occurred along the Japan Trench. 


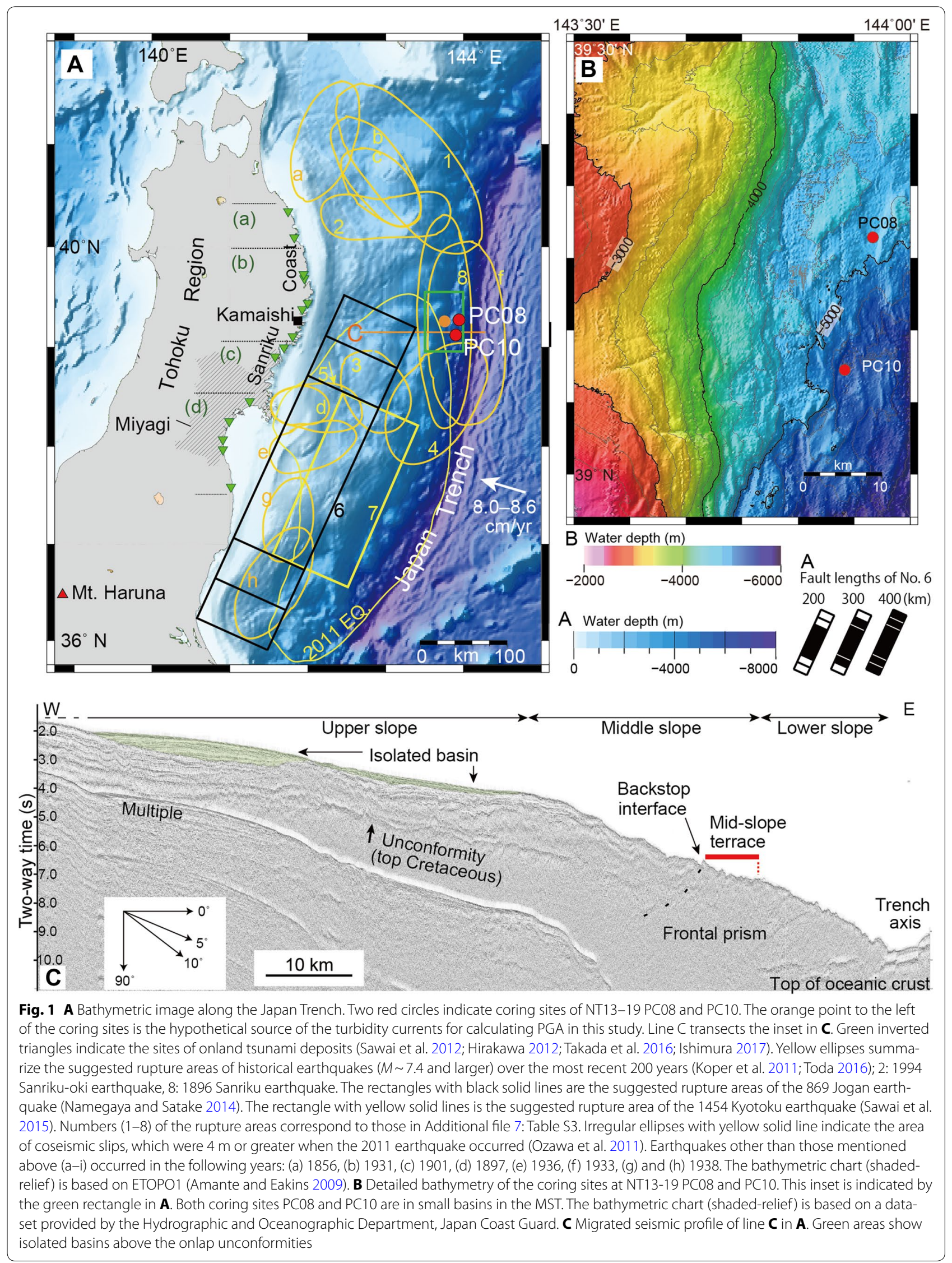




\section{Results and discussion}

\section{Characteristics of the turbidites and age model}

The two recovered cores are characterized by alternating bioturbated hemipelagites (diatomaceous mud) and massive event deposits with a sharp base and upward fining grading structure. The cores each have 12 distinct event deposits preserved in their upper $4 \mathrm{~m}$ (Fig. 2). The grading structure shows changes from "parallel or cross-laminated basal fine sand-coarse silt layer" to "upper mud layer" (Fig. 2, Additional file 1: Figure S1, Additional file 2: Figure S2). Sedimentary structures of event deposits suggest that the deposits are considered as "fine-grained turbidite" (Stow and Shanmugam 1980), except for T1-2 in PC10, which consists of only two semi-indurated gravels. Although the structure of the event deposits shows occasional disturbance by bioturbation, the basal layers are relatively well preserved. Not only the hemipelagites but also the event deposits contain few carbonates (Additional file 3: Figure S3), suggesting that the origins of the turbidity currents are below the carbonate compensation depth (CCD; Berger et al. 1976), which is deeper than the forearc basin.

A volcanic ash layer with a $2-3 \mathrm{~cm}$ thickness is observed in both cores. The ash layers are composed of pumice-type volcanic glass shards with hornblende and clinopyroxene as heavy minerals. The petrographic characteristics (heavy mineral composition, morphotypes of volcanic glass shards, and refractive index of glass shards: 1.505-1.509) of the ash layers are correlated with those of the Haruna-Futatsudake-Ikaho (Hr-FP) tephra (Ikehara et al. 2017), products of a historical eruption of Mt. Haruna during the 6th century (Geshi and Oishi 2011; Fig. 1A). For determining the depositional ages and correlation of the turbidites, radioisotopes $\left({ }^{137} \mathrm{Cs}\right.$ and excess ${ }^{210} \mathrm{~Pb}$; McHugh et al. 2016) and paleomagnetic secular variation (PSV) records (Kanamatsu et al. 2017) were used in addition to the tephra evidence. MST is located below the $\mathrm{CCD}$; therefore, ${ }^{14} \mathrm{C}$ dating cannot be used for these cores that contain few calcium carbonates. In the case of radioisotopes, horizons in the two cores that excess ${ }^{210} \mathrm{~Pb}$ detection limits (A.D. 1860) and the maximum for ${ }^{137}$ Cs (A.D. 1963; Peirson 1971) were referred to in previous studies (McHugh et al. 2016) (Figs. 2 and 3). The quality of the PSV records is excellent for deep-sea sediments. The obvious changes allow many of the turbidites in the two cores to be correlated with each other (Fig. 2, Additional file 4: Figure S4, Additional file 5: Table S1, Additional file 6: Table S2). The turbidites are numbered from $\mathrm{T} 1$ to $\mathrm{T} 12$ in descending order of age. Based on the age model and correlations, we found that the two cores have preserved $\sim 12$ turbidites (event deposits) during the last 4000 years. "Methods" section describes the specific procedure of the stratigraphic correlation between the turbidites in PC08 and PC10.

\section{Cause of the turbidite deposition and correlation of the upper turbidites with historical earthquakes}

Generally, in addition to gas-hydrate destabilization, earthquakes, and tsunamis, turbidity currents that deposit turbidites are triggered by events such as storms and hyperpycnal flows in coastal areas (e.g., Goldfinger et al. 2012; Polonia et al. 2013). Based on the submarine topography mentioned earlier, MST is difficult to be affected by shallow water areas in terms of the sediment supply. Besides, the compositions of the turbidites within the two cores suggest that the origins of the turbidity currents are below the CCD, suggesting that the main source of the turbidity currents is a scarp in the middle slope. In addition, no gas hydrates have been reported in this area. For these reasons, earthquakes that result in ground motion are the most-likely trigger of the turbidity currents.

The estimated depositional ages of the four turbidites above the Hr-FP can be related to the ages of historical earthquakes. It is possible that the uppermost turbidites $\mathrm{T} 1$ and $\mathrm{T} 1-2$ are related to the 2011 (Mw 9.0) and the 1896 (Mw 8.1) earthquakes based on the results from radioisotope dating. $\mathrm{T} 1$ is found out from each core top, and is immediately above the maximum for ${ }^{137} \mathrm{Cs}$ (A.D. 1963; Peirson 1971). T1-2 is immediately above excess ${ }^{210} \mathrm{~Pb}$ detection limit (A.D. 1860). From the stratigraphic relationship with PSV labels, the turbidites T2 (below PSV label "b" and above "c" in the inclinations, approximately A.D. 1470 and A.D. 1220) and T3 (around PSV label "d" and "B" approximately A.D. 730) can be attributed to the 1454 Kyotoku ( $M$ w 8.4 or larger) and the 869 Jogan $(M w \sim 9)$ earthquakes, respectively. Even though no other historical records are available, the estimated age of the turbidites implies a relatively shorter interval (100-300 years) prior to the last 2300 years, pointing to different depositional timings between the two cores for T6-T8 and T10-T12 (Fig. 3).

\section{Sensitivity of turbidity current generation to earthquake ground shaking}

Concerning the interpretation of these turbidite records, we must find a way to quantify the extent of the rupture areas and the magnitudes of the earthquakes recorded in the turbidite. As noted above, only great $(M \mathrm{w} \sim 8)$ or giant $(M w \sim 9)$ earthquakes are clearly recorded above $\mathrm{Hr}$-FP in the two cores. Based on this result, the sensitivity of turbidity-current generation to earthquake ground shaking is discussed below. Historical earthquakes over the last 200 years are mapped in Fig. 1A (Koper et al. 2011; Toda 2016). This distribution of past earthquakes 


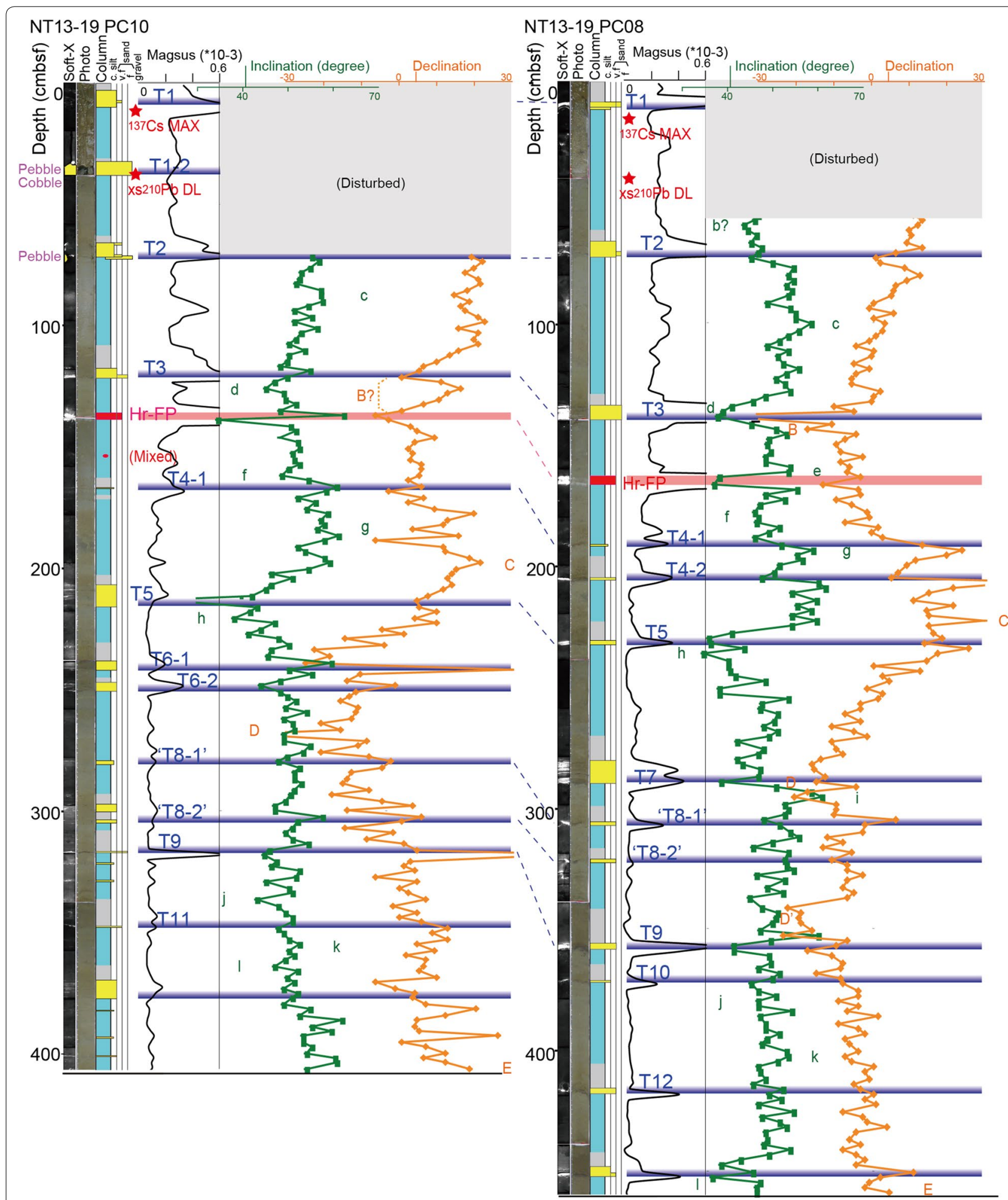

Fig. 2 Soft-X radiographs, photographs, lithological column, magnetic susceptibility, and PSV records. In the column, yellow layers indicate coarse layers (> course silt); blue layers are hemipelagite (silt clay); gray horizons are turbidite-mud; red layers and patch are tephra layers or patches. Apparent turbidites (event deposits) are indicated by blue lines, and are numbered beginning at the top layer. Relatively indistinct turbidites are assigned branch numbers. The letters "A"-"E" (relative declination) and "a"-"I" (inclination) added to the PSV records are PSV labels for prominent features of age control (Kanamatsu et al. 2017). Shaded intervals of the PSV record are horizons disturbed by inclinations of minimum axes of anisotropy of magnetic susceptibility (Kanamatsu et al. 2017). Stars indicate horizons at the excess ${ }^{210} \mathrm{~Pb}$ detection limit and the ${ }^{137} \mathrm{Cs}$ maximum (McHugh et al. 2016) 


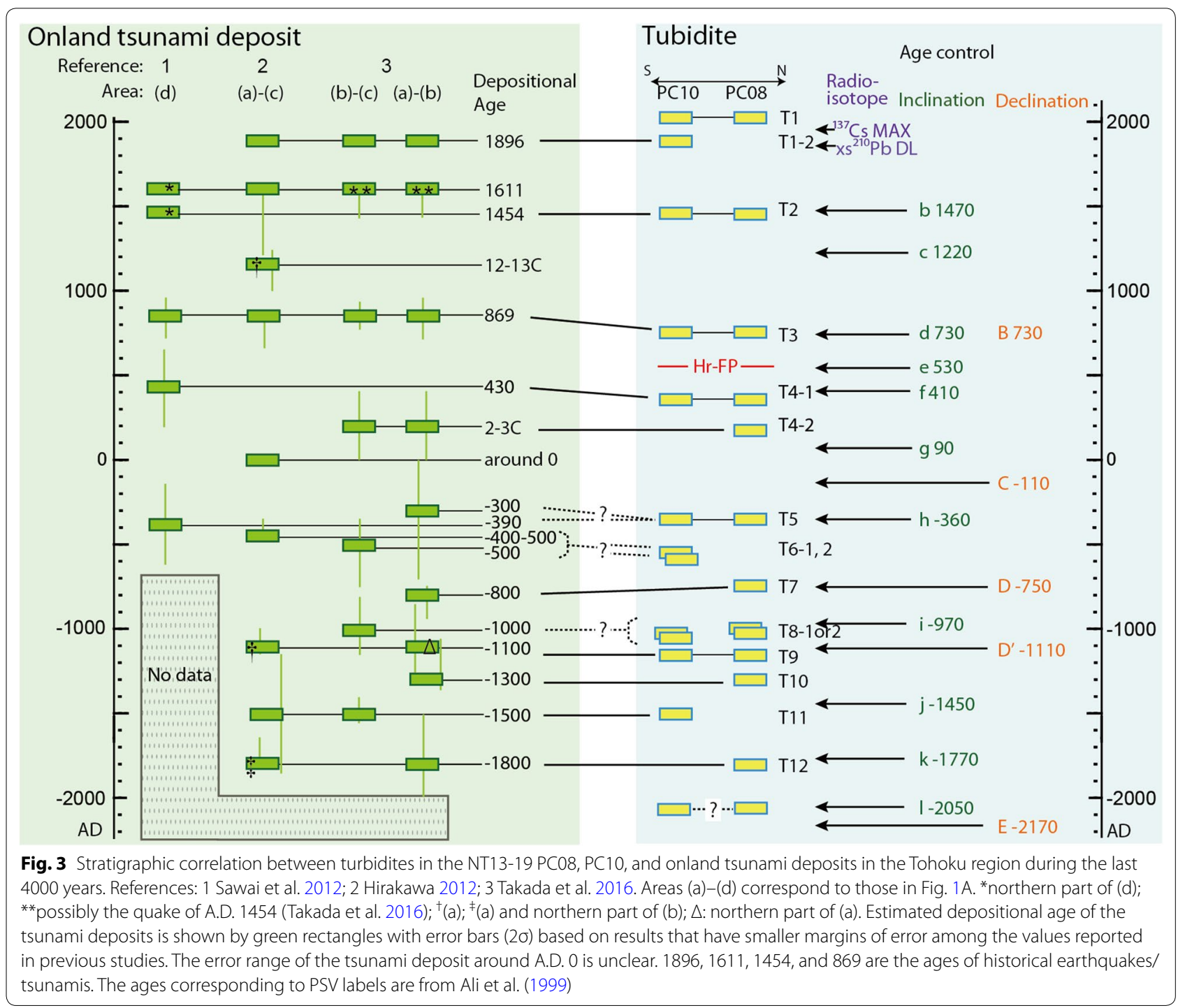

indicates that few large earthquakes (with $M \sim 7.5$ and larger) have occurred in the forearc off Kamaishi, which is near the coring sites. The reason of the distribution pattern has been discussed based on seismic tomography in the megathrust zone off Tohoku. Most large interplate thrust earthquakes occurred in high-velocity areas that may represent high-strength asperities (Huang and Zhao 2013); In contrast, a low-velocity area associated with abundant sediments supplied from the incoming plate lies off Kamaishi (Tsuru et al. 2002; Huang and Zhao 2013). Weak interplate locking off Kamaishi is also implied by the degree of periodicity and the dominant period of slow slip (Uchida et al. 2016). The absence of large earthquakes in the areas adjacent to the coring sites owing to these tectonic settings has likely facilitated the successive recording of the great-giant earthquakes in the cores. In this case, turbidity currents can be generated only by such great-giant earthquakes, and surface sediments could continue to accumulate during the other periods without being interrupted by earthquakes in adjacent areas. The accumulated sediments result in thick turbidites that are difficult to disturb by benthos activities mainly from the seafloor. These sedimentary conditions mean that only records of great-giant earthquakes have been preserved clearly as turbidites in the coring sites that we studied.

Next, based on the suggested rupture areas of historical earthquakes around the coring sites, we roughly estimated the peak ground acceleration (PGA) at the possible source zone of the turbidity currents resulting in the turbidites in the two cores (Fig. 1A) using an empirical attenuation relation commonly used in Japan (Additional 
file 7: Table S3; Si and Midorikawa 1999). In general, the initiation of slope failure depends on excess pore pressure caused by earthquake-induced ground acceleration (Seed and Idriss 1971). Other factors also contribute to actual slope failures, such as the duration of ground motion and the time elapsed since the previous earthquake, the latter of which is the period over which hemipelagite was deposited on the slope. We assume that slope failure was triggered simply by ground acceleration because the details of the historical earthquakes are unknown.

The estimation results infer that the PGA could be large (over $\sim 200 \mathrm{~cm} / \mathrm{s}^{2}$ ) at the hypothetical source zone, for fault models of the giant and great earthquakes recorded as the turbidites; the A.D. 869 Jogan (uniformslip model with a fault length of $200 \mathrm{~km}$; Namegaya and Satake 2014), 1454 Kyotoku (Sawai et al. 2015), 1896 Sanriku (Satake et al. 2017), and 2011 Tohoku (Yoshida et al. 2011)(No. 6, 7, 8 and a yellow irregular ellipse in Fig. 1A, Additional file 7: Table S3). On the other hand, great earthquakes that occur near the coring sites could have also produced large acceleration (over $\sim 240 \mathrm{~cm} / \mathrm{s}^{2}$ ) within $100 \mathrm{~km}$ from the area, such as the 1897 (Sato 1989) and 1994 Sanriku-oki (Nakayama and Takeo 1997) earthquakes (No. 4 and 2 in Fig. 1A, Additional file 7: Table S3). As for the 1897 earthquake, the rupture area is thought to be close to the trench axis. It has been reported that earthquakes with low short-period energy stand out near the trench axis (water depth $>3500 \mathrm{~m}$ ) (Koper et al. 2011; Lay et al. 2012; Huang and Zhao 2013). Considering that the ground acceleration caused by weak short-period radiation is generally slight, earthquakes near the trench axis have a lower potential for triggering turbidity currents in the source zone, than a case suggested by results from the attenuation relation. Note that, this speculation does not apply to the case in which earthquakes are extraordinarily large and/or their rupture areas lie just below the source zone, like the 1896 Sanriku earthquake.

However, the 1994 Sanriku-oki earthquake is not considered as the above-mentioned "near-trench" earthquake (Nakayama and Takeo 1997; Yamanaka and Kikuchi 2004). This earthquake is supposed to have caused larger ground acceleration at the hypothetical source zone, than those of the 869 Jogan (uniform-slip model with a fault length of $200 \mathrm{~km}$; Namegaya and Satake 2014) and 1454 Kyotoku (fault model in Sawai et al. 2015; 200 km long) earthquakes. After the 1994 earthquakes, dives of submersible "Shinkai 6500 " were performed at the northern MST $\left(40^{\circ} 7.8^{\prime}-10.5^{\prime} \mathrm{N}, 143^{\circ} 58.8^{\prime}-144^{\circ} 2.2^{\prime} \mathrm{E}\right)$. According to the reports, no evidence of resedimentation was found, even though the dive locations were only $25 \mathrm{~km}$ from the hypocenter of the earthquake (Ogawa et al. 1996). In terms of the 869 earthquake, 300 and $400 \mathrm{~km}$ long fault models have been assumed in addition to the model with a fault length of $200 \mathrm{~km}$, for a uniform-slip model (Namegaya and Satake 2014; Fig. 1A). Using fault parameters of these models for the calculations, the estimated PGAs can be significantly large (over $\sim 370 \mathrm{~cm} / \mathrm{s}^{2}$ ) compared to that of the 1994 earthquake, at the hypothetical source zone (Additional file 7: Table S3). Thus, the obvious turbidites $\mathrm{T} 3$ in the two cores may suggest that the fault models with a fault length of $300 \mathrm{~km}$ or longer are more probable for the 869 earthquake. The 869 Jogan tsunami deposits found in the Sanriku coast in recent years (Takada et al. 2016; Ishimura 2017) seem to support this inference. Similarly, the fault model of the 1454 earthquake is also based on a estimation with a minimum magnitude (Sawai et al. 2015). Given the turbidites T2, clearly recorded in the two cores, the rupture length of this earthquake could be much longer than $200 \mathrm{~km}$.

\section{Correlation of offshore turbidite records with onland tsunami deposits}

Subsequently, we compared the estimated turbidite depositional ages with those of onland tsunami deposits reported by previous studies (Sawai et al. 2012; Hirakawa 2012; Takada et al. 2016; Ishimura 2017). The ages of the tsunami deposits that disagree with the turbidites, such as those from the 12-13 century, and A.D. 1611, may have been related to tsunamis begun in other far-field areas or submarine landslides instead of earthquakes along the Japan Trench (Fig. 3). Recently, Ishimura (2017) re-examined the depositional ages of tsunami deposits at Koyadori [located near the middle latitude of area (b) in Fig. 1A], and found tsunami deposits formed in A.D. 510-240 ("E5 bed") and A.D. 260-270 ("E6 bed"). The E5 bed may be correlated with the tsunami deposits from A.D. 430 in the Sendai and Ishinomaki plains (Fig. 3; Sawai et al. 2012), and may also be correlated with the T4-1 turbidite. The E6 bed has no correlating turbidite, thus suggesting that it may be the product of a tsunami of far-field or landslide origin, although the bed may also be correlated with a tsunami deposit formed around A.D. 0 reported by Hirakawa (2012); (Fig. 3). Except for the few disagreements, many of the estimated ages of the tsunami deposits in the Tohoku region can be correlated with those of turbidites in the two cores. In addition, the tsunami deposits are thought to have been deposited at different times across the north and the south regions between 2000 and 4000 years ago (Takada et al. 2016). The turbidite depositional ages may also be correlated with those ages, thus reflecting the latitudinal difference of the coring sites. PC08 is located approximately $20 \mathrm{~km}$ north of PC10, and the ages of its turbidites are better correlated with those of onland tsunami deposits found on the northern part of the Sanriku coast (Figs. 1 and 3). 
The turbidite ages of PC10 correspond to those of the southern part. Overall, these turbidites seem to have been deposited alternately at northern and southern sites, during the periods between concurrent depositional events (e.g., T5, T8, T9, and next to T12) at intervals of 500900 years. The difference in timing of the turbidite deposition in the two cores is likely significant, considering its correlation with the distribution of tsunami deposits on the Sanriku coast. In other words, the turbidites recorded in only one core (T6-T7, T10-T12) may record the difference of source region of earthquakes off the Sanriku coast, even though PC10 and PC08 are only $20 \mathrm{~km}$ apart.

\section{Supercycle}

A "supercycle" of giant $(M \sim 9)$ earthquakes with a recurrence interval of $\sim 700$ years and superimposed on the cycle ( 37 years) of earthquakes off Miyagi (Fig. 1A) has been proposed along the Japan Trench (Satake and Fujii 2014; Satake 2015; Fig. 4a). These authors have also suggested that the large coseismic slip near the trench axis of the 2011 Tohoku earthquake can be explained by this model of earthquake cycles. The typical slip of the offMiyagi earthquakes is $\sim 2 \mathrm{~m}$, accompanied by a cumulative slip of $\sim 6 \mathrm{~m}$ per century, as the subduction rate of the Pacific plate is $\sim 8 \mathrm{~m}$ per century. Such cumulative slips have been interpreted to have been released by infrequent earthquakes with recurring at an interval of $\sim 700$ years (Satake 2015).
Considering the suggested magnitudes and source regions of the past earthquakes along the Japan Trench, the events recorded concurrently in the two cores studied above may correspond to earthquakes that are a part of this supercycle (Fig. 4b). The earthquakes related to the supercycle are implied to have occurred over at least the last 4000 years, and the cycle may have shortened slightly in recent years (Fig. 4b). If the earthquake supercycle is regulated by cumulative slip as previous studies have indicated, these shorter intervals are a potentially influenced by the decrease in number of earthquakes that were recorded only in one core. These earthquakes (other than giant earthquakes) might have also contributed to partial releases of cumulative slip in common with the off-Miyagi earthquakes. Meanwhile, the accumulated slip off the Sanriku coast may have contributed to the size of giant earthquakes, such as the 2011 Tohoku and the 869 Jogan earthquakes.

\section{Conclusions}

Deep-sea seismo-turbidites in two piston cores recovered from the MST along the Japan Trench have preserved the earthquake records associated with tsunamis that have damaged the Pacific coast of the Tohoku region over the last 4000 years. Approximately 12 turbidites, or event deposits, have been formed at the coring sites, and we dated them with a PSV method along with tephrochronology and radioisotopes. These turbidites were deposited alternately in the northern and southern sites

b

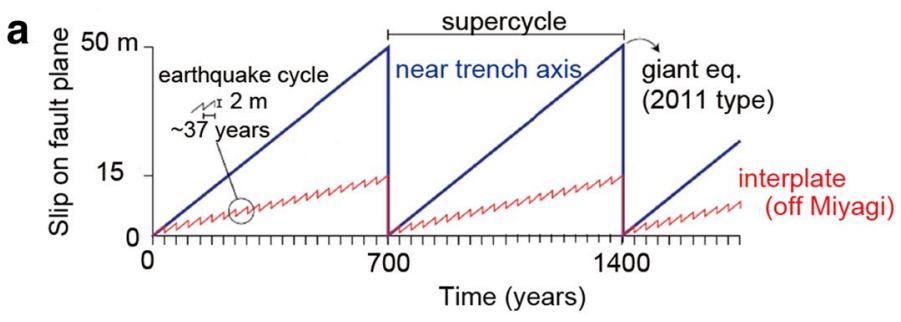

Turbidite depotision

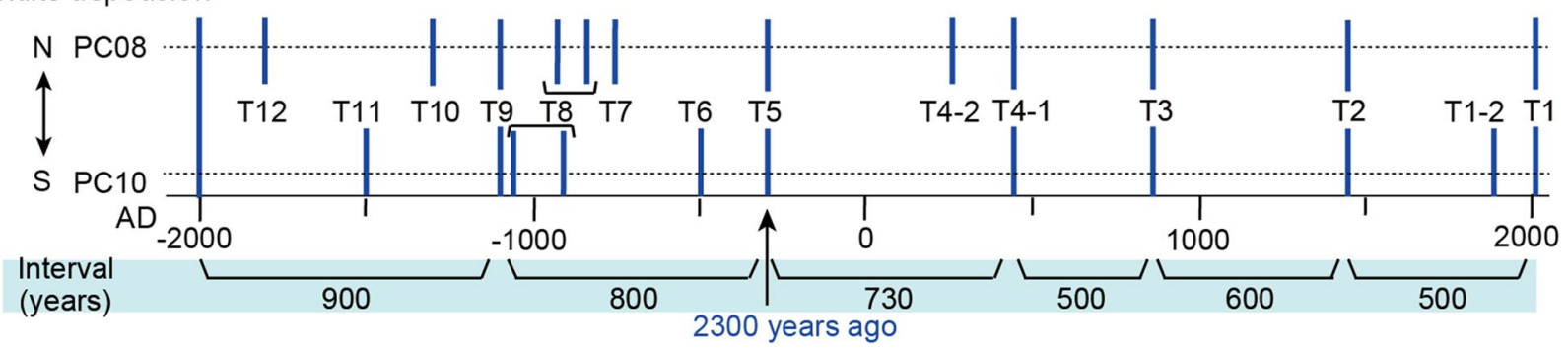

Fig. 4 a Schematic for earthquake supercycle off Miyagi in red and near the trench axis in blue (Satake and Fujii 2014; Satake 2015). If slip accumulated from the remainders from off-Miyagi earthquakes is released by giant earthquakes, the recurrence interval or supercycle measures $\sim 700$ years (Satake 2015). b Time-series diagram for turbidite depositions of NT13-19 PC08 and PC10. Earthquakes related to the supercycle are implied to have occurred for the last 4000 years, and the cycle has become slightly shorter in recent years, considering the concurrent depositional events. The types of earthquakes recorded only in one core have decreased in recent years 
during the periods between concurrent depositional events occurring at intervals of 500-900 years. The concurrent depositional events likely correspond to a supercycle of giant $(M \sim 9)$ earthquakes along the Japan Trench, recurring at an interval of $\sim 700$ years. The earthquakes related to the supercycle have occurred over at least the last 4000 years, and this recurrence interval has shortened slightly in recent years. Decreases in the release of accumulated slip caused by earthquakes in the northern and southern areas off the Sanriku coast have likely affected the recent shortening of the supercycle.

\section{Methods}

\section{Soft-X radiograph}

Recovered cores were carefully observed visually, and detailed sedimentary structures were observed using soft-X radiographs. The samples for soft-X radiographs were prepared continuously using plastic cases (length $20 \mathrm{~cm}$, width $5 \mathrm{~cm}$, thickness $1 \mathrm{~cm}$ ) with no gap, from one side of the halved cores, following visual descriptions and photographs on board. The samples were then refrigerated and analyzed with soft X-ray imaging. Smear slides were observed and used to determine the horizons of typical sedimentary facies (Additional file 3: Figure S3).

\section{Magnetic susceptibility and PSV records (inclination and relative declination)}

MST is located below CCD (Berger et al. 1976); therefore, ${ }^{14} \mathrm{C}$ dating method cannot be used for these cores as they contain few calcium carbonates. Therefore, we used a PSV method that has not been previously used for dating the deep-sea turbidites. The measurement procedure and the PSV records and magnetic susceptibility results are based on Kanamatsu et al. (2017). Obvious peak and trough intervals on the graphs of paleomagnetic inclinations and declinations (PSV labels; "A"-"E" and "a"-"i" in Fig. 2) were correlated with those of a Holocene secular variation curve from Lake Biwa (Ali et al. 1999) to infer the age of the cores. Refer to Additional file 4: Figure S4, Additional file 5: Table S1, Additional file 6: Table S2 for more details. Generally, directional deflections are clearly marked in the turbidite layers in our profiles (Fig. 2). These deflections are likely related to coarse material intercalations. Thus, the intervals, which show larger deflections, may not indicate proper PSV records. Therefore, we made stratigraphic correlations without those data.

\section{Stratigraphic correlation between the turbidites in PC08 and those in PC10}

Stratigraphic correlations between the turbidites in NT13-19 PC08 and those in PC10 are based on the stratigraphic relationships of radioisotope marker horizons (McHugh et al. 2016), Hr-FP tephra, and PSV labels in PSV records (Kanamatsu et al. 2017). Magnetic susceptibility is also taken into account (Fig. 2, Additional file 5: Table S1, Additional file 6: Table S2). In the following explanation, the letters "A"-"E" (relative declination) and "a"-"i" (inclination) are PSV labels.

Specific procedure:

1. [Above Hr-FP] Three turbidites (event deposits) occurred in PC08 and four occurred in PC10. Those turbidites show similar stratigraphy in the two cores, except for T1-2 which is indistinct in PC08. T1 is found out from each core top, immediately above the maximum for ${ }^{137}$ Cs (A.D. 1963; Peirson 1971). T1-2 is immediately above the excess ${ }^{210} \mathrm{~Pb}$ detection limit (A.D. 1860). T2 is above "c" on the inclination in each core and is below "b" in PC08. T3 is adjacent to " $\mathrm{d}$ " and " $\mathrm{B}$ " in both cores. Although the PSV record of PC10 is slightly different from that of PC08, we consider that PC08 has better PSV records because of the relatively rapid accumulation.

2. [Hr-FP-"h" on the inclinations] T4-1 (below " $\mathrm{f}$ ") and T5 (immediately above " $h$ ") are clearly marked in both cores. A turbidite below T4-1 in PC08 is named T4-2 (below "g" and above "C"). In PC10, T4-2 is not obvious from the soft $\mathrm{X}$-ray radiograph, although magnetic susceptibility profiles show slight fluctuations in the horizon that correspond to T4-2.

3. [" $h$ " on the inclinations-" $D$ " on the declinations] We considered a turbidite immediately above " $\mathrm{D}$ " in PC08 as T7, and two turbidites in the middle horizon between "h" and "D" as T6-1 and T6-2 in PC10. T6 of PC08 and $\mathrm{T} 7$ of $\mathrm{PC} 10$ are not obvious in soft $\mathrm{X}$ radiographs, although magnetic susceptibility profiles show slight fluctuations in the horizon corresponding to the turbidites.

4. ["D" on the declinations-T9] " $\mathrm{D}$ " and "D" in PC10 cannot be marked because the PSV record of PC10 is unclear relative to that of PC08. Therefore, a characteristic turbidite with peculiarly high magnetic susceptibility is found out and named as T9 in each core. Two turbidites occur above T9 in PC08 and PC10. The turbidites below " $\mathrm{D}$ " are named as "T8-1"; the turbidites below "T8-1" are "T8-2" in PC08 and PC10. However, "T8-1" and "T8-2" in PC08 cannot be correlated with those of PC10, considering the thicknesses of the hemipelagites between " $D$ " and T-9. If the accumulation rates are assumed to have been nearly constant, "T8-1" and "T8-2" of PC08 would have formed later than those of PC10 (Fig. 4).

5. [Below T9] Three turbidites, T10 (above “j”), T11 (below "j", and above "k"), and T12 (below "k," and above "l") are evident in PC08 and PC10. In addition to these, another turbidite is observed the vicinity of 
"l" in PC08. On the other hand, a turbidite below "l" is found in PC10. Given that this correlation is relatively unclear, these two turbidites are not numbered in the figure.

In this study, the identification of turbidites (event deposits) is based only on the obvious sedimentary structure (or evidently bioturbated event layer) to have a clear criterion for identification. For example, horizons with high magnetic susceptibility lie between $\mathrm{T} 2$ and $\mathrm{T} 3$ in both PC08 and PC10; however, soft-X radiographs, photos, and visual observations (sediment grain size, sedimentary structure, and sediment color) do not present evidence of resedimentation. In this case, these layers probably indicate environmental changes in the bottom water. Hence, we do not consider these horizons to be turbidites or event deposits in this study.

\section{Preliminary estimation of PGA}

We estimated approximate maximum accelerations at an assumed source point $\left(39.25^{\circ} \mathrm{N}, 143.75^{\circ} \mathrm{E}\right.$; Fig. 1A) of the turbidity currents, which resulted in the turbidites when historical earthquakes occurred. The assumed source point is located on the slope adjacent to the coring sites, and $\sim 4000 \mathrm{~m}$ in depth because of few carbonate fractions in the turbidites (Additional file 3: Figure S3). Considering the accuracies of the suggested rupture areas of the historical earthquakes, we chose only one assumed source point for the two cores for the calculations, except for the 1994 Sanriku-oki earthquake as an example. Actual source point for the two cores is considered to have been differ from one another; however, if we chose different source points for each core, the resulting difference of calculated values would have little meaning in this case. Eight historical earthquakes and the 2011 Tohoku earthquake that occurred around the coring sites are selected for calculation (Fig. 1A, Additional file 7: Table S3). Fault parameters of the earthquakes have been discussed in previous studies, and we summarize them in Additional file 7: Table S3. The 1933 earthquake (rupture area $\mathrm{f}$ in Fig. 1A) is excluded from the estimations, because of the source fault in the incoming plate.

We use an empirical attenuation relation commonly used in Japan (Si and Midorikawa 1999):

$$
\log (\mathrm{PGA})=b-\log (x+c)-0.003 x,
$$

where

$$
\begin{aligned}
& b=0.5 M \mathrm{w}+0.0043 D+d+0.61 \\
& c=0.0055 * 10^{0.50 M \mathrm{w}} .
\end{aligned}
$$

Here $x$ is the shortest distance from the fault plane (fault distance); $D$ is the focal depth (average depth of the fault plane); $d$ corresponds to the type of earthquake (crustal: 0.00 ; interplate: 0.01 ; intraplate: 0.22 ). We applied 0.01 for the calculations because the earthquakes we estimated were all interplate earthquakes. Si et al. (2016) reported that strong ground motion will stop to increase with $M \mathrm{w}$ for earthquakes with $M \mathrm{w}$ larger than 8.3 (it is called magnitude saturation) when using fault distance. Therefore, we have substituted 8.4 for $M \mathrm{w}$ in the equation, for the A.D. 869, 1454, and 2011 earthquakes. This attenuation formula was derived from records of ground motion on land. Therefore, the actual PGAs in the deep sea close to the Pacific plate were possibly stronger. Along the Japan Trench, the subducting Pacific plate has been reported to guide high-frequency seismic wave efficiently more than the overriding (landward) plate (Furumura and Kennett 2005).

\section{Additional files}

Additional file 1: Figure $\mathbf{S 1}$. High-resolution soft $X$ radiographs and color photos of NT13-19 PC08. Solid arrow: basal part of turbidite (sand or coarse silt); dotted arrow: turbidite mud. T1-T12: turbidite numbers correspond to those in Figs. 2, 3, and 4. A-l: horizons of the smear slides in Additional file 3: Figure S3: Hr-FP: Haruna-Futatsudake-Ikaho tephra.

Additional file 2: Figure S2. High-resolution soft $X$ radiographs and color photos of NT13-19 PC10. . Solid arrow: basal part of turbidite (sand or coarse silt); dotted arrow: turbidite mud. T1-T11: turbidite numbers correspond to those in Figs. 2, 3, and 4. Hr-FP: Haruna-Futatsudake-Ikaho tephra.

Additional file 3: Figure S3. Selected representative smear slide images showing typical microscopic characteristics of basal sand $\sim$ coarse silt layer and upper mud layer of the turbidites, in addition to the hemipelagites in NT13-19 PC08 core. Both the hemipelagites and the turbidites (both of the basal sands and the turbidite muds) contain few carbonate fractions, suggesting that the origins of turbidity currents are below carbonate compensation depth (CCD). The diatomaceous hemipelagic mud $(A, D$, and $G$ ) is almost composed of diatoms and siliceous sponge spicules accompanied by few clastics. Turbidite muds ( $B, E$, and $H$ ) consist of diatoms, siliceous sponge spicules, and few clastics, with amorphous organic matter particles. Basal sands of the turbidite (C, F and I) include rock fragments and minerals such as quartz and aegirine-augite, as well as diatoms, siliceous sponge spicules, and organic matter particles. A: diatomaceous hemipelagic mud, $51 \mathrm{~cm}$ (in core depth); B: turbidite (T2) mud, $64 \mathrm{~cm}$; C: basal sand of the turbidite T2, $71 \mathrm{~cm}$; D: diatomaceous hemipelagic mud, $194 \mathrm{~cm}$; E: turbidite (T4-2) mud, $202 \mathrm{~cm}$; F: basal sand of the turbidite T4-2, $205 \mathrm{~cm}$; G: diatomaceous hemipelagic mud, $268 \mathrm{~cm}$; $\mathrm{H}$ : turbidite (T7) mud, $281 \mathrm{~cm}$; I: basal sand of the turbidite T7, $290 \mathrm{~cm}$. a: parallel nicols; b: crossed nicols. Scale bars: $100 \mu \mathrm{m}$. The horizons of A-l are shown in Additional file 1: Figure S1.

Additional file 4: Figure S4. Correlations between PSV records of NT319 (PC08 and PC10) and those of Lake Biwa (Ali et al. 1999). The letters "A"-"G" (relative declination) and "a"-"n" (inclination) added to the PSV records are PSV labels for prominent features of age control (Ali et al. 1999; Kanamatsu et al. 2017).

Additional file 5: Table S1. Variations in magnetic susceptibility, declination, and inclination obtained from NT13-19 PC08.

Additional file 6: Table S2. Variations in magnetic susceptibility, declination, and inclination obtained from NT13-19 PC10.

Additional file 7: Table S3. Estimated PGAs and parameters of fault models used in the trial calculations. 


\section{Abbreviations}

MST: mid-slope terrace; PSV: paleomagnetic secular variation; Hr-FP: HarunaFutatsudake-Ikaho tephra; PGA: peak ground acceleration; JAMSTEC: Japan Agency for Marine-Earth Science and Technology.

\section{Authors' contributions}

$\mathrm{KU}, \mathrm{Kl}$, and $\mathrm{CM}$ observed turbidites. $\mathrm{KU}$ and $\mathrm{KI}$ also analyzed the detailed turbidite stratigraphy. KU identified components of sediments by use of the smear slides and estimated ground motion. TK analyzed paleomagnetic data of the cores and managed the cruise. All authors contributed to the writing of the manuscript and to scientific discussions. All authors read and approved the final manuscript.

\section{Author details \\ ${ }^{1}$ Geological Survey of Japan, National Institute of Advanced Industrial Science and Technology (AIST), Tsukuba Central 7, 1-1-1 Higashi, Tsukuba 305-8567, Japan. ${ }^{2}$ Research and Development Center for Earthquake and Tsunami, Japan Agency for Marine-Earth Science and Technology (JAMSTEC), 2-15 Natsushima-cho, Yokosuka 237-0061, Japan. ${ }^{3}$ Earth and Environmental Sci- ences, Queens College, City University of New York, 65-30 Kissena Boulevard, Flushing, NY 11367, USA. ${ }^{4}$ Marine Geology and Geophysics, Lamont-Doherty Earth Observatory of Columbia University, PO Box 1000, Palisades, NY 10964, USA. ${ }^{5}$ Atmosphere and Ocean Research Institute, The University of Tokyo, 5-1-5, Kashiwanoha, Kashiwa-shi, Chiba 277-8564, Japan.}

\section{Acknowledgements}

We express our heartfelt thanks to the officers, crew, and on-board scientists of the NT13-19 cruise including T. Aoki who provided assistance with core recovery. We also acknowledge K. Arai for providing seismic profile of Fig. 1C. Finally, we thank anonymous reviewers for constructive comments on the earlier version of this manuscript.

\section{Competing interests}

The authors declare that they have no competing interests.

\section{Availability of data and materials}

Additional files 1, 2, 3, 4, 5, 6, 7 are available. Correspondence and requests for materials should be addressed to KU.

\section{Consent for publication}

Not applicable.

\section{Ethics approval and consent to participate}

Not applicable.

\section{Funding}

This work was financially supported in part by the Ministry of Education, Culture, Sports, Science and Technology (MEXT) of Japan via the research projects "Geophysical and Geological Studies of Earthquakes and Tsunamis for off-Tohoku District, Japan" and "Regional Study on Hazard Mitigation along the Nankai Trough", and Kaken-hi "Japan Trench Deep-Sea Research Project for Assessing Shallow Seismic Slips and Their History (No. 260000002)."This work was also financially supported in part by "Study on Coastal Sediments" funded by the Geological Survey of Japan (GSJ), AIST, and "Tephra in the Japan Trench Cores" by a special research fund of the Research Institute of Geology and Geoinformation, GSJ, AIST.

\section{Publisher's Note}

Springer Nature remains neutral with regard to jurisdictional claims in published maps and institutional affiliations.

Received: 6 July 2017 Accepted: 17 March 2018

Published online: 07 April 2018

\section{References}

Abe H, Sugeno Y, Chigama A (1990) Estimation of the height of the Sanriku Jogan 11 earthquake-tsunami (AD 869) in the Sendai Plain. Zisin 2nd ser 43:513-525 (in Japanese)
Ali M, Oda H, Hayashida A, Takemura K, Torii M (1999) Holocene paleomagnetic secular variation from Lake Biwa. Geophys J Int 136:218-228

Amante C, Eakins BW (2009) ETOPO1 1 arc-minute global relief model: procedures, data sources and analysis. NOAA technical memorandum NESDIS NGDC-24. National Geophysical Data Center, NOAA. https://doi. org/10.7289/v5c8276m. Accessed 03 Mar 2015

Arai K, Inoue T, Ikehara K, Sasaki T (2014) Episodic subsidence and active deformation of the forearc slope along the Japan Trench near the epicenter of the 2011 Tohoku Earthquake. Earth Planet Sci Lett 408:9-15

Berger WH, Adelseck CG Jr, Mayer LA (1976) Distribution of carbonate in surface sediments of the Pacific Ocean. J Geophys Res 81:2617-2627

Cadet JP, Kobayashi K, Lallemand S, Jolivet L, Aubouin J, Bouleue J, Dubois J, Hotta H, Ishii T, Konishi K, Niitsuma N, Shimamura H (1987) Deep scientific dives in the Japan and Kuril Trenches. Earth Planet Sci Lett 83:313-328

DeMets C, Gordon RG, Argus DF (2010) Geologically current plate motions. Geophys J Int 181:1-80

Furumura T, Kennett BLN (2005) Subduction zone guided waves and the heterogeneity structure of the subducted plate: intensity anomalies in northern Japan. J Geophys Res 110:B10302. https://doi. org/10.1029/2004JB003486

Geshi N, Oishi M (2011) The ${ }^{14} \mathrm{C}$ ages of the late Pleistocene-Holocene volcanic products erupted from the Haruna volcano. Bull Geol Surv Japan 62:177-184 (in Japanese)

Goldfinger C, Han Nelson C, Morey A, Johnson JE, Gutierrez-Pastor J, Eriksson AT, Karabanov E, Patton J, Gracia E, Enkin R, Dallimore A, Dunhill G, Vallier T (2012) Turbidite event history: methods and implications for paleoseismicity of the Cascadia subduction zone. USGS Prof Paper 1661-F, US Geol Surv, Reston. p 184

Gutierrez-Pastor J, Han Nelson C, Goldfinger C, Escutia C (2013) Sedimentology of seismo-turbidites off Cascadia and Northern California active tectonic continental margins, Northeast Pacific Ocean. Mar Geol 336:99-119

Hirakawa K (2012) Outsize tsunami sediments since last years along the Japanand Kuril-Trench: a tentative idea on source and supercycle. Kagaku 82:172-181 (in Japanese)

Huang Z, Zhao D (2013) Mechanism of the 2011 Tohoku-oki earthquake (Mw 9.0) and tsunami: insight from seismic tomography. J Asian Earth Sci 70-71:160-168

Ikehara K, Kanamatsu T, Nagahashi Y, Strasser M, Fink H, Usami K, Irino T, Wefer G (2016) Documenting large earthquakes similar to the 2011 Tohoku-oki earthquake from sediments deposited in the Japan Trench over the past 1500 years. Earth Planet Sci Lett 445:48-56

Ikehara K, Usami K, Kanamatsu K, Danhara T, Yamashita T (2017) Three important Holocene tephras off the Pacific coast of the Tohoku region, Northeast Japan: implications for correlating onshore and offshore event deposits. Quat Int 456:138-156

Ishimura D (2017) Re-examination of the age of historical and paleo-tsunami deposits at Koyadori on the Sanriku Coast. Northeast Japan Geosci Lett 4:11. https://doi.org/10.1186/s40562-017-0077-4

Ishimura D, Miyauchi T (2015) Historical and paleo-tsunami deposits during the last 4000 years and their correlations with historical tsunami events in Koyadori on the Sanriku Coast, northeastern Japan. Prog Earth Planet Sci 2:16. https://doi.org/10.1186/s40645-015-0047-4

Kanamatsu T, Usami K, McHugh CMG, Ikehara K (2017) High-resolution chronology of sediment below CCD based on Holocene paleomagnetic secular variations in the Tohoku-oki earthquake rupture zone. Geochem Geophys Geosys 18:2990-3002. https://doi.org/10.1002/2017GC006878

Kanamori H (1972) Mechanism of tsunami earthquakes. Phys Earth Planet Interior 6:346-359

Kawamura K, Laberg JS, Kanamatsu T (2014) Potential tsunamigenic submarine landslides in active margins. Mar Geol 356:44-49

Kon'no E, Iwai J, Takayanagi Y, Nakagawa H, Onuki Y, Shibata T, Mii H, Kitamura N, Kotaka T, Kataoka J (1961) Geological observations of the Sanriku coastal region damaged by the tsunami due to the Chile earthquake in 1960, vol 52. Contr Inst Geol Paleont, Tohoku Univ, Sendai, pp 1-45 (in Japanese)

Koper KD, Hutko AR, Lay T, Ammon CJ, Kanamori H (2011) Frequency-dependent rupture process of the 2011 Mw 9.0 Tohoku Earthquake: comparison of short-period $\mathrm{P}$ wave backprojection images and broadband seismic rupture models. Earth Planet Space 63:599-602 
Lay T, Kanamori H, Ammon CJ, Koper KD, Hutko AR, Ye L, Yue H, Rushing TM (2012) Depth-varying rupture properties of subduction zone megathrust faults. J Geophys Res 117:B04311. https://doi.org/10.1029/2011JB009133

McHugh CM, Kanamatsu T, Seeber L, Bopp R, Cormier M-H, Usami K (2016) Remobilization of surficial slope sediment triggered by the A.D. $2011 \mathrm{Mw}$ 9 Tohoku-Oki earthquake and tsunami along the Japan Trench. Geology 44:391-394. https://doi.org/10.1130/G37650.1

Minoura K, Nakaya S (1991) Traces of tsunami preserved in inter-tidal lacustrine and marsh deposits; some examples from northeast Japan. J Geol 99:265-287

Minoura K, Imamura F, Sugawara D, Kono Y, Iwashita T (2001) The 869 Jogan tsunami deposit and recurrence interval of large-scale tsunami on the Pacific coast of northeast Japan. J Natr Dis Sci 23:83-88

Nakayama W, Takeo M (1997) Slip history of the 1994 Sanriku-haruka-oki, Japan, earthquake deduced from strong-motion data. Bull Seism Soc Am 87:918-931

Namegaya Y, Satake K (2014) Reexamination of the A.D. 869 Jogan earthquake size from tsunami deposit distribution, sumulated flow depth, and velocity. Geophys Res Lett 41:2297-2303

Namegaya Y, Yata T (2014) Tsunamis which affected the Pacific coast of eastern Japan in medieval times inferred from historical documents. Zisin 66:73-81

Ogawa Y, Fujikura K, Iwabuchi Y, Kaiho Y, Izumi N, Inoue A, Nogi Y, Taira K, Kimura T, Lee IT, Kodera T, Nagai S, Okano H, Ikegami A, Fujioka K, Kuwano T (1996) Dive report of "Shinkai 6500" 1995 Cruise at the Northern Japan Trench landward slope (Dives 272-277). Geomorphology, Geology and Biology of the Sanriku escarpment. J Deep Sea Res. 12:1-22 (in Japanese). http://www.godac.jamstec.go.jp/catalog/data/doc_catalog/ media/shinkai12 01.pdf. Accessed 2 Jun 2017.

Ozawa S, Nishimura T, Suito H, Kobayashi T, Tobita M, Imakiire T (2011) Coseismic and postseismic slip of the 2011 magnitude-9 Tohoku-oki earthquake. Nature 475:373-376

Patton JR, Goldfinger C, Morey AE, Ikehara K, Romsos C, Stoner J, Djadjadiharja Y, Ardhyasturi SU, Gaffer EZ, Viscaino A (2015) A 6600 year earthquake history in the region of the 2004 Sumatra-Andaman subduction zone earthquake. Geosphere 11:1-62

Peirson DH (1971) Worldwide deposition of long-lived fission products from nuclear explosions. Nature 234:79-80

Polonia A, Panieri G, Gasperini L, Gasparotto A, Bellucci LG, Torelli L (2013) Turbidite paleoseismology in the Calabrian Arc subduction complex (Ionian Sea). Geochem Geophys Geosys 14:112-140

Pouderoux H, Proust JN, Lamarche G (2014) Submarine paleoseismology of the northern Hikurangi subduction margin of New Zealand as deduced from turbidite record since 16 ka. Quat Sci Rev 84:116-131

Reading HG, Richards M (1994) Turbidite systems in deep-water basin margins classified by grain size and feeder system. Bull Am Assoc Petrol Geol 78:792-822

Satake K (2015) Geological and historical evidence of irregular recurrent earthquakes in Japan. Phil Trans R Soc A 373:20140375

Satake K, Fujii Y (2014) Review: source models of the 2011 Tohoku Earthquake and long-term forecast of large earthquakes. J Disaster Res 9:272-280

Satake K, Namegaya Y, Yamaki S (2008) Numerical simulation of the A.D. 869 Jogan tsunami in Ishinomaki and Sendai plains. Ann Rep Active Fault Paleoearthq Res 8:71-89 (in Japanese)

Satake K, Namegaya Y, Yamaki S (2017) Different depths of near-trench slips of the 1896 Sanriku and 2011 Tohoku earthquakes. Geosci Lett 4:33

Sato R (1989) Handbook for Japanese Earthquake faults parameters. Kajima Institute Publishing, Tokyo

Sawai Y, Namegaya Y, Okamura Y, Satake K, Shishikura M (2012) Challenges of anticipating the 2011 Tohoku earthquake and tsunami using coastal geology. Geophys Res Lett. https://doi.org/10.1029/2012GL053692
Sawai Y, Namegaya Y, Tamura T, Nakashima R, Tanigawa K (2015) Shorter intervals between great earthquakes near Sendai: scour ponds and a sand layer attributable to A.D. 1454 overwash. Geophys Res Lett 42:4785-4800. https://doi.org/10.1002/2015GL064167

Seed HB, Idriss IM (1971) Simplified procedure for evaluating soil liquefaction potential. J Soil Mech Found Div 97:1249-1273

Shipboard Scientific Party (1980) Site 440: Japan Trench midslope terrace, Leg57. Init Rept DSDP 56\&57:225-231

Si H, Midorikawa S (1999) New attenuation relationships for peak ground acceleration and velocity considering effects of fault type and site condition. J Struct Constr Eng 523:63-70 (in Japanese). https://www.jstage.jst. go.jp/article/aijs/64/523/64_KJ00004087596/_article/-char/en. Accessed 30 Mar 2018

Si H, Koketsu K, Miyake H (2016) Attenuation characteristics of strong ground motion from megathrust earthquakes in subduction zone-on the pass effects. J Japan Assoc Earthq Eng 16: 96-105 (in Japanese). https:// www.jstage.jst.go.jp/article/jaee/16/1/16_1_96/_article/-char/en. Accessed 22 Feb 2018

Stow DAV, Shanmugam G (1980) Sequence of structures in fine-grained turbidites: comparison of recent deep-sea and ancient flysch sediments. Sed Geol 25:23-42

Suzuki W, Aoi S, Sekiguchi H, Kunugi T (2011) Rupture process of the 2011 Tohoku-Oki mega-thrust earthquake (M9.0) inverted from strong-motion data. Geophys Res Lett 38:LO0G16. https://doi.org/10.1029/2011 gl049136. Accessed 30 Mar 2018

Takada K, Shishikura M, Imai K, Ebina Y, Goto K, Koshiya S, Yamamoto H, Igarashi A, Ichihara T, Kinoshita H, Ikeda T, River division department of prefectural land development, Iwate prefecture government (2016) Distribution and ages of tsunami deposits along the Pacific coast of the Iwate Prefecture. Ann Rep Active Fault Paleoearthq Res 16:1-52 (in Japanese)

Tanioka Y, Satake K (1996) Fault parameters of the 1896 Sanriku tsunami earthquake estimated from tsunami numerical modeling. Geophys Res Lett 23:1522-1549

Tappin DR, Watts P, McMurtry GM, Lafoy Y, Matsumoto T (2001) The Sissano, Papua New Guinea tsunami of July 1998_-offshore evidence on the source mechanism. Mar Geol 175:1-23

Toda S (2016) Crustal earthquakes. In: Moreno T, Wallis S, Kojima T, Gibbons W (eds) The geology of Japan. Geol Soc, London, pp 371-408

Tsuru T, Park JO, Miura S, Kodaira S, Kido Y, Hayashi T (2002) Along-arc structural variation of the plate boundary at the Japan Trench margin: implication of interplate coupling. J Geophys Res 107:ESE 11-1-ESE 11-15. https://doi. org/10.1029/2001JB001664

Uchida N, linuma T, Nadeau RM, Bürgmann R, Hino R (2016) Periodic slow slip triggers megathrust zone earthquakes in northeastern Japan. Science 351:488-492

von Huene R, Culotta R (1989) Tectonic erosion at the front of the Japan Trench convergent margin. Tectonophys 160:75-90

von Huene R, Lallemand SE (1990) Tectonic erosion along the Japan and Peru convergent margins. Geol Soc Am Bull 102:704-720

von Huene R, Langeseth N, Nasu N, Okada H (1980) Summary, Japan Trench transect. Initial Report of the DSDP 56-57, Pt. 1:473-488

Yamanaka Y, Kikuchi M (2004) Asperity map along the subduction zone in northeastern Japan inferred from regional seismic data. J Geophys Res. https://doi.org/10.1029/2003JB002683

Yoshida Y, Ueno H, Muto D, Aoki S (2011) Source process of the 2011 off the Pacific coast of Tohoku Earthquake with the combination of teleseismic and strong motion data. Earth Planets Space 63:565-569 